\title{
Water Resources Management in Vulnerable Ecosystems: Quiroz River Basin, Piura
}

\author{
By Marta Tostes ${ }^{1}$, Mirian Espejo ${ }^{2}$, Enrique Macedo $^{3}$, Fidel Torres ${ }^{4}$
}

\begin{abstract}
According to the IPCC (2014), access to water resources is increasingly limited due to the effects of climate change; in consequence, vulnerability of ecosystems and their inhabitants increases. Thus, it is necessary to develop socio-organizational capacities to mitigate and adapt to this scenario, where retribution mechanisms for ecosystem services (MRSE for its Spanish acronym) become more relevant. The research attempts to analyze the coordination among agents involved in sustainable water resources management, to face climate change vulnerability in high biodiversity areas. For this purpose, the implementation of the Quiroz-Chira water fund will be studied as a case that generates institutionalism for sustainability of this mechanism and that represents an important social innovation that can be replicated. The methodology has a descriptive scope and applies qualitative techniques that complement secondary sources systematized with WebQDA software. Results indicate high vulnerability of the analyzed basin districts and a correct governance in this innovation, both with a sustainable development approach oriented to conservation of water potential. This implies good articulation for implementation of the MRSE and promotion of interests' unification between contributors and water resources retributive entities.
\end{abstract}

Keywords: Climate change, Sustainable development, Watershed, Governance, Ecosystem services

\section{Introduction}

The American continent is one of the greatest biodiversity sources, as it houses " $26 \%$ of the terrestrial biodiversity conservation [...] being the moorland and Amazon forests the richest tropical alpine zone and the wettest tropical forests in the world respectively" (IPBES, 2018, pág. 6). The effects of climate change threaten this biological wealth, since access to water is increasingly limited. The role of inhabitants, through development of socio-organizational capacities, is essential to adapt to this scenario. Multi-level governance processes strengthen these capacities and enable the generation of greater opportunities to incorporate, in decision-making, their knowledge on ecosystem management and equity (IPBES, 2018).

Peru has Andean moorlands and cloud forests in its northern area, currently threatened by climate change effects. Due to its location, they play a fundamental role in the

\footnotetext{
| ${ }^{1}$ Main Professor at Pontificia Universidad Católica del Perú (PUCP) in the Management Science Academic Department. Grupo de Investigación en Gestión de la Innovación (GIGI-PUCP) coordinator

2Social Manager from Management Faculty of Pontificia Universidad Católica del Perú (PUCP), Specialized in Conflict Prevention and Sustainable Social Management. Grupo de Investigación en Gestión de la Innovación (GIGI-PUCP) researcher

${ }^{3}$ Business Manager from Management Faculty of Pontificia Universidad Católica del Perú (PUCP). Grupo de Investigación en Gestión de la Innovación (GIGI-PUCP) researcher

${ }^{4}$ Fidel Torres Guevara is Doctor in Biochemistry, Biochemistry Master and Botanical Biologist. Mountain Institute researcher. President of the Agricultural Science and Innovation Network in AGRORED NORTE
} 
catchment, retention and distribution of annual rainfall in the basin headwaters to which they belong. Such is the case of the Piura region, which developed the Regional System for Conservation of Natural Areas (SRCAN) and prioritized the Humid Mountain and Moorland Forests as a conservation corridor (Ministerio del Ambiente, 2014).

This research analyzes governance, fundamental axis for climate change adaptation, in the Quiroz-Chira Water Fund (FAQCH for its Spanish acronym). It is a Remuneration Mechanism for Ecosystem Services (MRSE for its Spanish acronym), created to preserve the forests and moorlands in the upper part of the Quiroz river basin. This is one of the first experiences of its type in Peru. These ecosystems are vulnerable to climate change and institutional innovations such as FAQCH contribute to the adaptation of the geographic space and its inhabitants. However, this experience needs not only validation, but also systematization to enable its up scaling.

Five sections constitute this study. The first section presents a literature review about the main concepts. The next ones explain the research context and the proposed methodology. Final sections include the main research findings and their conclusions.

\section{Literature Review}

Climate change causes increase in average temperatures and rainfall throughout the entire American continent, with adverse impacts on its ecosystems (IPBES, 2018). In consequence, it exposes "ecosystems, people, societies and economic sectors to risks" (IPCC, 2014, p. 38). These, "arise from interaction between a hazard (caused by a climate change related phenomenon or trend), vulnerability (susceptibility to damage) and exposure (people, assets or ecosystems at risk) "(IPCC, 2014, p. 38). About vulnerability, it "...is the degree to which a system is affected by, or unable to cope with, the adverse climate change effects including climate variability and extreme events" (IPCC, 2007, pág. 48). In this research, water system vulnerability is prioritized. It has a social dimension explicitly translated into components that are "a group of elements with common characteristics which, when they exist, provide a security environment in the face of extreme hydrometeorological events, affecting human development and linked to safe drinking water access." (Ministerio del Ambiente, Energía y Telecomunicaciones, 2011, pág. 19). These elements are infrastructure, services and human condition. They are important because if they are missing, vulnerability increases.

The climate change impact also affects services obtained from ecosystems, which are "used (actively or passively) to produce human welfare" (Fisher, Turner, \& Morling, 2009, p. 645). Ecosystem services are those direct and indirect economic, social and environmental benefits that people obtain from the proper functioning of ecosystems (El Peruano, 2016). Water regulation is considered in this type of services, as well as "soil conservation through preservation of native vegetation that protects water resources and dependent human activities (water supply, hydroelectric energy, irrigation and other water uses)" (Frickmann \& Medeiros, 2018, pág. 33).

On the other hand, Integrated Water Resources Management (GIRH for is Spanish acronym) is a "process that promotes coordinated development and management of water, land and related resources, in order to maximize the resulting economic and social well-being in an equitable manner without compromising sustainability of vital 
ecosystems "(Global Water Partnership, 2000, p. 22). Water management will allow for "reduction but not elimination of impact risks on continental aquatic ecosystems caused by climate change" (IPCC, 2014, p. 39).

The pressure of climate change effects on water regulation, gives way to the MRSE, that seeks to "generate, guide, transfer and invest economic, financial and non-financial resources, so that contributor(s) and ecosystem service retributive entities establish an agreement oriented to the conservation, recovery and sustainable use of the sources of ecosystem services "(Alban, 2017, p. 26). Management related to these mechanisms for water quality and sustainability assurance must follow one of the GIRH principles established in the Dublin agreement: "water development and management must be based on a participatory approach, involving users, planners and policy-makers at all levels" (International Conference on Water and the Environment, 1992, p. 4). This principle is closely related to governance defined as "a set of mechanisms, spaces, routes and forms for decision-making [...] that allows identifying how and where that decisionmaking power is exercised" (Hofstede, Vásconez, \& Cerra, 2015, pág. 20).

Governance is a dimension of social innovation and consists of new practices or methods to carry out traditional processes that involve community and beneficiaries' participation and mobilization (Domanski, Monge, Quitiaquez, \& Rocha, 2016). Likewise, governance relates to the socio-organizational capacity to climate change adaptation (Hofstede, Vásconez, \& Cerra, 2015). It is important to mention that good governance characterizes by "efficient and effective compliance of the institutional framework with participation of different stakeholders and following a series of essential principles" (Iza, 2019, pág. 5).

\section{Context}

Basins through the department of Piura allow its population access to water resources for use primarily in agro industry and energy production, as well as for their own consumption. Among them, the Quiroz river basin that belongs to the so-called Binational Catamayo Chira $(\mathrm{CCH})$ basin stands out and provides $21.21 \%$ of its area of Environmental Water Services (Kometter , 2013).

The Quiroz river is born 3,900 meters above sea level in "Misal hill (Shiantaco) of the Huamaní mountain range, in Ayabaca province and runs through the districts of Pacaipampa, Ayabaca, Sícchez, Paimas and Suyo" (Alban, 2017, pág. 29). In addition, together with the Macará river basin, they present "the highest values for provision of environmental water service, due to the presence of vegetation cover in the area" (Alban, 2017, págs. 19-20).

However, "the ecosystems in the upper part of the Quiroz river basin (mainly moorlands and cloud forests) suffer fragmentation and degradation jeopardize the availability and water supply of the San Lorenzo Hydraulic System” (Alban, 2017, pág. 30). Therefore, in order to safeguard water resources availability and to compensate the conservation work carried out by residents of different communities, the NGO Nature and Culture International (NCI) established the Quiroz-Chira River Water Fund (FAQCH). Its objective is "to capture and manage economic resources that allow to finance conservation of the forests and moorlands of the upper basin of the Quiroz river and the 
Chira system, and to support the sustainable development of families that directly use the water resource" (Naturaleza y Cultura Internacional, 2020, pág. s.n.).

This fund is in its initial phase. Priority was to a group of 578 beneficiary families from the peasant communities of Samanga and Tapal and the properties of Huamba, San Juan de Cachiaco and San Pablo, who contribute to water resources conservation through the constitution and care of two private conservation areas and a natural conservation area (FAQCH, 2020). According to the income generated by the fund, other contributing and beneficiary communities will be added to the first group. The FAQCH obtains its resources through "economic recognition for actions carried out by contributors" (El Peruano, 2016). It is important to mention that remuneration is not compulsory, as it is not regulated by the National Water Authority (ANA for its Spanish acronym) nor by the Ministry of Agriculture and Irrigation (MINAGRI for its Spanish acronym). It is a suggestion given to the retributive entities to invest in the conservation of the basin. The Users Board of the San Lorenzo Hydraulic Sector (JUHSAL for its Spanish acronym), the Users Board of the Chira Hydraulic Sector (JUSHCH for its Spanish acronym), Ayabaca Provincial Municipality, Pacaipampa District Municipality, and Nature and International Culture (NCI) constitute this group.

With regard to the first retributive entity, the JUHSAL initially contributed " $1 \%$ of the fee and has committed itself to reach a maximum contribution of $5 \%$ as a fixed amount from 2019 on" (Alban, 2017, pág. 74). On the other hand, JUSHCH "contributed S/ 27 000 during 2015 and S/ 28000 during 2016" (Alban, 2017, pág. 74). As to the remunerative municipalities, "the funds come from public investment ongoing projects and from current expenses that cover technical assistance to the communities by the municipal staff' (Alban, 2017, pág. 59). On the part of NCI, valued and cash contributions are made corresponding to personnel expenses and supplies or equipment purchases to implement actions in the projects, respectively (Alban, 2017).

\section{Methodology}

The research has two main objectives. The first one is to propose new variables that relate to water system vulnerability. These can complement the variables proposed by Tostes, Villavicencio and Motta (2019) for evaluation of the vulnerability index to climate change in the Quiroz river basin districts. The objective of that study was to develop a multi-criteria analysis to measure vulnerability at district level, taking into account the performance measurement subjects. For each subject, authors analyzed vulnerability through various variables: population; species and ecosystems; municipalities' functions, services and environmental goods; infrastructure; and economic, social and cultural assets.

Inasmuch as this research gives greater relevance to water system vulnerability, after identifying the vulnerability index, it was necessary to look for variables that can fortify and adapt to the fieldwork context observed. To that effect, the Ministry of Environment, Energy and Telecommunications together with the National Meteorological Institute (2011) of Costa Rica with UNDP support, presented a report with indicators that were taken into account. This report presents different variables divided into three components: services, infrastructure and human condition. Although 
the Quiroz river basin index is represented by its districts vulnerability: Pacaipampa, Ayabaca, Sícchez, Paimas and Suyo, it is relevant to consider the following indicators:

Table 1. Quiroz River Basin: selected water system vulnerability social variables, 2020

\begin{tabular}{|l|l|}
\hline Component & Variables \\
\hline \multirow{3}{*}{ Infrastructure } & Housing without aqueduct \\
\cline { 2 - 2 } & Housing with septic tank \\
\cline { 2 - 2 } & Road infrastructure \\
\hline \multirow{3}{*}{ Human Condition } & Water availability per capita \\
\cline { 2 - 2 } & Housing without electricity \\
\cline { 2 - 2 } & Water consumption of agricultural sector \\
\cline { 2 - 2 } & Unmet basic needs \\
\cline { 2 - 3 } & Human development index (IDH for its Spanish acronym) \\
\hline
\end{tabular}

Adapted from: Ministry of Environment, Energy and Telecommunications of Costa Rica, 2011

After identifying the basin's vulnerability and the climate change effects on ecosystem services, this research concentrates on the second objective that is to analyze governance around one MRSE, the Quiroz-Chira Water Fund (FAQCH). The analysis includes verifying compliance with the five variables proposed for good governance establishment by UNDP (2013), Hasen (2016), IUCN (2019). Therefore, the variables are as follows: monitoring system, traditional knowledge, access to information, participation spaces and accountability.

Table 1. FAQCH: Proposal for good governance variables, 2020

\begin{tabular}{|l|l|}
\hline Variable & Description \\
\hline $\begin{array}{l}\text { Monitoring } \\
\text { system }\end{array}$ & $\begin{array}{l}\text { Evaluate compliance with processes and key agreements in the framework of } \\
\text { projects developed with the FAQCH }\end{array}$ \\
\hline $\begin{array}{l}\text { Traditional } \\
\text { knowledge }\end{array}$ & $\begin{array}{l}\text { Consider the knowledge of peasant communities or native people about the } \\
\text { environment to complete technical or scientific knowledge in the FAQCH }\end{array}$ \\
\hline $\begin{array}{l}\text { Access to } \\
\text { information }\end{array}$ & $\begin{array}{l}\text { Accurate, effective and open communication from and for contributors, } \\
\text { retributive entities and the FAQCH }\end{array}$ \\
\hline $\begin{array}{l}\text { Participation } \\
\text { spaces }\end{array}$ & Creation of joint decision-making mechanisms \\
\hline Accountability & Transparency in economic, social and environmental results \\
\hline
\end{tabular}

Source: Adapted from PNUD 2013, Hasen, 2016 and Iza, 2019.

In the process of selecting information gathering tools for this descriptive study, primary sources such as interviews, observations and technical meetings, were used during the visit to the Quiroz river basin. Based on the variables, interview guides were prepared for specialists of Nature and International Culture (NCI) and the Quiroz-Chira Water Fund. With regard to fieldwork in the Quiroz river basin, Pacaipampa district was visited, specifically San Juan de Cachiaco and San Pablo properties. Observations to the Water Fund projects were made and meetings were held with their representatives. Likewise, to complement secondary sources, the FAQCH representatives provided detailed reports that enriched the findings of the selected governance variables. The information obtained in the gathering process was systematized in the WebQDA software for 
subsequent analysis.

The following section presents the main findings in the analysis of the five good governance variables.

\section{Findings}

This section has two parts. The first part presents evidences of the need to incorporate new variables (See Table 2) to allow a more accurate evaluation of the vulnerability index associated with water resources of the Quiroz river basin. The second part analyzes the main findings related to governance variables around the FAQCH.

The research by Tostes, Villavicencio and Motta (2019) found that initially the vulnerability index for climate change of the districts that conform the Quiroz river basin is 4.24, which under guidelines of the referred research is considered high. However, it is necessary to incorporate variables to perform a new vulnerability index evaluation, based on the context observed in fieldwork. These variables are divided into three components: infrastructure, services and human condition.

Recommendations regarding infrastructure are to consider the following variables: housing without aqueduct, housing with septic tanks and road infrastructure. The reason is that "a resilient and reliable infrastructure is essential for transport of goods and people, for energy and clean water supply, for trade, communication and emergency response to disasters" (Naturaleza y Cultura Internacional, 2017, pág. 11). This aspect was observed during the visit to the upper basin, where roads and access to communities were hardly accessible, especially in rainy season.

With regard to the services component, in the upper basin of the Quiroz river "there is little drinking water coverage and most have access to the electricity network, although in poor condition" (Hofstede, Vásconez, \& Cerra, 2015, pág. 85). During the visit to Totora, hamlet in Pacaipampa, its inhabitants, who belong to the Association of Farmers Conservationists of Forests, Moorland and Mist of the Predio San Juan (ACOBOSPA for the Spanish acronym), expressed their need to have electrical network service in their homes and appropriate public lighting to enable them to perform their daily tasks adequately.

In relation to agricultural activities, inhabitants "have small, non-technical parcels with precarious irrigation systems that, together with precarious road and material infrastructure, generate high sensitivity to eventual climate change impacts" (Hofstede, Vásconez, \& Cerra, 2015, pág. 132). Despite this unfavorable situation, ACOBOSPA members seek to preserve the ecosystem and contribute to building resilience in their area. An example is that together with NCI organization, they monitor moorland with rain gauges that measure the amount of water that contributes to the Quiroz river basin. These actions influence lower basin users who are taking advantage of moorland water and have realized that contributors can really be active actors in ecosystem conservation (ACOBOSPA, personal communication, January 7, 2020).

As for the third component, human condition, it is important to highlight that poor road infrastructure generates economic isolation and limits access to health services. On the one hand, inhabitants have difficulties entering markets outside their boundaries and are forced to produce corn, peas, wheat and potatoes mainly for their own consumption. 
Likewise, the difficulty of timely access to health facilities is aggravated by three main reasons: remoteness from health centers, impossibility to transit roads during rainy seasons and poor availability of drinking water in health centers. These situations give rise to the occurrence of infectious diseases in the population.

After description of the findings related to the vulnerability of the Quiroz river basin, the main variables around governance of the FAQCH are analyzed. These are monitoring system, traditional knowledge, access to information, participation spaces and accountability.

As to the monitoring system variable, it is necessary to mention that contributors provide ideas to generate new projects. Each proposal becomes an investment plan that contains the objective, timetable and budget according to the retributive entities' contribution. With the prepared proposal, the FAQCH and the community sign an agreement to start activities. Then, monitoring follows up the project framework processes and agreements. In order to carry out the follow-up, the fund's technical secretariat mentioned that progress was made "in the issues of institutionalism, internal documents, strategic planning and communication systems (...) we continue in this learning process in productive matters, as well as in effective conservation and indicators measurement" (Abel Calle, personal communication, April 22, 2020).

Likewise, monitoring comes from two supervision axes. On one hand, the Directory board evaluates the fund's spending, verifies fulfillment of its mission and looks for new contributing partners (Paul Viñas, personal communication, April 17, 2020). The fund's mission is the conservation of the moorlands' ecosystem located in the upper basin of the Quiroz river and currently this fund benefits five communities. However, the objective is to benefit progressively the approximately sixty communities found throughout the basin. The elements to prioritize communities were the existence of conservation areas in their surroundings and the trust developed from previous NCI work with them, which achieves creation and strengthening of bond between the community and the fund.

The work of NCI in the technical secretariat stands out as the field operational arm that verifies and supports work with the communities and makes the necessary coordination. At the beginning of the year, they supervise activities that are in the closing phase. Projects include reforestation activities that are performed during rain periods (Viñas, personal communication, April 17, 2020).

A mechanism that contributes to this variable is the creation of a good governance platform that monitors compliance with agreements between contributors and retributive entities in conformity with Law No. 30215, MRSE Law (2016). Since the FAQCH creation was prior to the enactment of this law, there was no monitoring platform in this fund. However, on its own initiative and based on its organizational structure, this aspect is strengthened. The organization consists of a general assembly, a board of directors, a technical secretariat, technical offices and a citizen participation committee (Calle, personal communication, April 22, 2020).

With regard to the second variable, traditional knowledge, the FAQCH considers important the customs and community traditions in which it has incidence through the projects. They state: "with our projects we do not impose things, we work in an articulated and consensual way respecting their identity (...) based on trust we develop 
projects according to each area's reality"(Calle, personal communication, April 22, 2020). Likewise, the knowledge of the communities is relevant "regarding landscape and biodiversity, it is interesting to learn what they know about plant properties, trees that help to maintain the soil or the humidity and trees that grow near springs" (Viñas, personal communication, April 17, 2020). Traditional knowledge not only implies information related to the topics of the projects developed in their area, but also to their particular form of organization that enables them to work in an articulated way and to resume ancestral applications so that they are not lost over time. This way families have a perception "about the importance of both the access to and creation of new knowledge and the appreciation of their own knowledge as instruments to explore new productive, organizational and management opportunities" (Hofstede, Vásconez, \& Cerra, 2015, pág. 160). An example of this are the minkas, a form of collaborative work based on reciprocity, where there is no salary but exchange for similar activity or food between community members. (Viñas, personal communication, April 17, 2020).

Minkas, a form of collaborative work based on reciprocity, where there is no salary but exchange for similar activity or food between community members.

The third variable, access to information, refers to accurate, effective and open communication from the FAQCH to contributors and retributive entities and other stakeholders. As to communication directed towards contributors and retributive entities, the FAQCH has internal documents and communication systems that enable equitable access to information. Starting with investment plans preparation to project closures, both actors have access to letters and technical and financial progress reports (Calle, personal communication, April 22, 2020). Furthermore, it is necessary to hold meetings between both parties in order to prioritize the implementation of new projects (Viñas, personal communication, April 17, 2020).

In addition to the above-mentioned channels, participation of contributors and retributive entities in informal spaces is also important. Such is the case of festivities celebrated by retributive entities, which allow access to photographic registration panels showing project progress and to detailed explanation of the work, giving visibility so it can be replicated in another area (Calle, personal communication, April 22, 2020). The photographic record facilitates understanding of the activities carried out in the upper part of the basin and gives support to the technical explanation provided. It is important to note that festivities celebrated by retributive entities bring together other potential partners and communities, and serve as a visibility space for the work carried out by the FAQCH and conservation-oriented contributors.

Moreover, communication of the FAQCH to other interest groups is worth noting and for this purpose, it uses different communication channels. As they state: "we have a website, Facebook and Instagram [...] also publications in magazines and local newspapers such as El Tiempo or La República where, in its weekly magazine La Semana, we publish the current activities"(Calle, personal communication, April 22, 2020).

For the FAQCH the trust that exists between communities and the actors' transparency is an intrinsic requirement. Thus, to have constant communication between contributor and retributive entities is extremely important for sustainability. Access to information must be complemented with the next variable, participation spaces. In these 
environments, contributors and retributive entities can have a certain degree of influence on the decisions taken and the actions to be carried out. The identified spaces for joint decision-making were citizen participation committees, internships and training workshops.

It is necessary to remember that the fund's organizational structure has a citizen participation committee that performs each year's accountabilities. It invites stakeholders and presents them with information of what has been done and the way money has been used; it is an environment for exchange of experiences and opinions. In addition, part of the fund is the board of directors. Its members will be in charge of supervising the proper resources management, and all members elect them through a public act in which each one casts its vote. (Naturaleza y Cultura Internacional, 2014).

The FAQCH encourages workshops and internships for community and retributive entities members, generating a learning and knowledge exchange environment. Since 2014, the internships allow retributive entities members to see on site the implemented activities in the communities and to talk with their people. This has allowed them to observe tangible results of their contributions and to share the experience to attract more members (Viñas, personal communication, April 17, 2020). The workshops, given for contributors, were forest management, organic fertilizers, nursery management, capacity strengthening, burning and illegal logging control, and silage (Naturaleza y Cultura Internacional, 2017, pág. 56).

Finally, there is the accountability variable, linked to transparency in the economic, social and environmental results of projects prepared from the FAQCH. Data obtained during the interview showed that a monthly information collection is made of the disbursements received in the fund's joint account from its boards. This account rendering report is presented to the general assembly and to a public hearing where retributive entity members and contributors participate. The boards are overseen by the local water authority, which requests their work plan where they include the approximate contribution percentage for conservation of the upper basin (Calle, personal communication, April 22, 2020). It is important to emphasize that the money that is received in the fund's account is not delivered in cash to contributors, because it is channeled to projects aimed at preserving and improving life quality (Viñas, personal communication, April 17, 2020). As previously mentioned, the fund has an organizational structure that strengthens transparency. The citizen participation committee plays a fundamental role in "rendering annual basis accounts, and inviting to those meetings many more actors [...] it has helped to maintain trust with both contributors and retributive entities and to work during five consecutive years and to have various tangible and measurable results" (Paul Viñas, personal communication, April 17, 2020). Likewise, it is necessary to highlight the role of peasant communities, because their leadership and organization makes work more transparent and bearable. Finally, another element to take into account is that the FAQCH received in 2018 the "Antonio Brack Egg National Environmental Award" in the category "protection and recovery of ecosystems and natural resources" as an example of the performance of its activities with full transparency and fulfilling the objectives for which it was created (Abel Calle, personal communication, April 22, 2020). 


\section{Conclusions}

Based on the findings presented, the introduction of this MRSE represents a high potential for social innovation in districts from the Quiroz river basin with high climate change vulnerability. The water system perspective, with three components: infrastructure, services and human condition, allows for a more comprehensive vision closer to the reality evidenced in the basin.

On the other hand, after defining and analyzing the variables related to good governance around the FAQCH, it is concluded that this mechanism is duly articulated between the agrarian system agents of the lower plains with those of the basin nascent. At the same time, it fulfills the objective of collecting and managing economic resources for the moorlands and cloud forests conservation that are present in the upper basin of the Quiroz river.

Finally, it is necessary to point out that the current good coordination between the fund's retributive entities and contributors, allows for an eventual expansion of its scope, thus contributing to its dissemination to ensure social innovation, as well as sustainability. However, recommendations are to strengthen participation, accountability and monitoring mechanisms to avoid possible conflicts between new actors that will be added in the coming years.

\section{References}

Alban, L. (2017). Fondo del Agua Quiroz- Chira. Obtenido de http://www.bosquesandinos.org/wpcontent/uploads/2017/02/FAQCH-FINAL-WEB.pdf

Domanski, D., Monge, N., Quitiaquez, G., \& Rocha, D. (Edits.). (2016). Innovación Social en Latinoamérica. Bogotá.

Decreto Supremo-No 009-2016-MINAM. Ley de Mecanismos de Retribución por Servicios Ecosistémicos (2016)

FAQCH. (27 de Marzo de 2020). Obtenido de https://www.faqch.com/detalle_prod2.php?id=7

Fondo del Agua Quiroz-Chira. (27 de Marzo de 2020). Fondo del Agua Quiroz-Chira. Obtenido de https://www.faqch.com/nosotros.php

Frickmann, C. E., \& Medeiros, R. (2018). Quanto vale o verde: a importância econômica das unidades de conservação brasileiras. Rio de Janeiro: Conservação Internacional.

Global Water Partnership. (2000). Integrated Water Resources Management. Estocolmo: GWP.

Hasen, F. N. (2016). Gobernanza sobre servicios ecosistémicos a escala local: caso de estudio sobre la provisión de agua en la comununa de Panguipulli, región de los ríos. Universidad Austral de Chile, Valdivia. Obtenido de http://cybertesis.uach.cl/tesis/uach/2016/egh348g/doc/egh348g.pdf

Hofstede, R., Vásconez, S., \& Cerra, M. (Edits.). (2015). Vivir en los páramos: Percepciones, vulnerabilidades, capacidades y gobernanza ante el cambio climático. Quito: UICN.

International Conference on Water and the Environment. (1992). The Dublin Statement and Report of the Conference. Dublín: ICWE.

IPBES. (2018). The regional assessment report on Biodiversity and Ecosystem Services for the Americas. Obtenido de https://ipbes.net/sites/default/files/2018_americas_full_report_book_v5_pages_0.pdf

IPCC. (2007). Climate change 2007 Synthesis Report. Obtenido de https://www.ipcc.ch/site/assets/uploads/2018/02/ar4_syr_full_report.pdf

IPCC. (2014). Cambio Climático 2014. Obtenido de https://www.ipcc.ch/site/assets/uploads/2018/02/SYR_AR5_FINAL_full_es.pdf

Iza, A. (Ed.). (2019). Gobernanza para la adaptación basada en ecosistemas. Gland, Suiza: UICN. Obtenido de https://portals.iucn.org/library/sites/library/files/documents/EPLP-089-Es.pdf

Kometter, R. (2013). Fondo ambiental para la gestión participativa de la cuenca alta del Río Quiroz en Piura, Perú. 
Ministerio de Educación. (2016). Piura, ¿cómo vamos en educación? Lima. Obtenido de http://escale.minedu.gob.pe/documents/10156/4228634/Perfil+Piura.pdf

Ministerio del Ambiente. (2014). Los Sistemas Regionales de conservación: Avances y lecciones aprendidas. Lima.

Ministerio del Ambiente, Energía y Telecomunicaciones. (2011). Análisis del Riesgo actual del sector bídrico de Costa Rica ante el cambio climático para contribuir a mejorar el desarrollo bumano. Costa Rica.

Naturaleza y Cultura. (2017). El Fondo del Agua Quiroz-Chira .

Naturaleza y Cultura Internacional (2014). [Película]. Recuperado el 22 de 04 de 2020, de https://www.youtube.com/watch?v=F9mQULqfh9E

Naturaleza y Cultura Internacional. (2017). Alternativas de financiamiento público y privado del Fondo De Agua Quiroz-Chira. Piura: Edítalo.

Naturaleza y Cultura Internacional. (30 de marzo de 2020). Obtenido de http://www.naturalezaycultura.org/spanish/htm/peru/fondo-rio-quiroz.htm

PNUD. (2013). User's Guide on Assessing Water Governance. Estocolmo.

Tostes, M., Villavicencio, A., \& Motta, C. (2019). Vulnerability index elaboration for climate change adaptation in Peru. European journal of sustainable development . 